\title{
PENGARUH TINGKAT YOGURT DAN WAKTU FERMENTASI TERHADAP KECERNAAN IN VITRO BAHAN KERING, BAHAN ORGANIK, PROTEIN, DAN SERAT KASAR KULIT NANAS FERMENTASI
}

\section{EFFECT OF DIFFERENT LEVEL OF YOGHURT AND TIME OF FERMENTATION ON IN VITRO DIGESTIBILITY OF DRY MATTER, ORGANIC MATTER, CRUDE PROTEIN AND CRUDE FIBRE OF FERMENTED PINEAPPLE PEEL}

\author{
Nurhayati*, Nelwida, dan Berliana \\ Fakultas Peternakan, Universitas Jambi, Jl. Raya Jambi - Muara Bulian Km. 15 Mendalo, Jambi, 36361
}

\section{INTISARI}

Penelitian dilaksanakan untuk melihat pengaruh tingkat yogurt dan waktu fermentasi terhadap kecernaan in vitro bahan kering, bahan organik, protein, dan serat kasar kulit nanas fermentasi. Penelitian dilakukan menggunakan Rancangan Acak Lengkap pola faktorial dengan 2 faktor yaitu tingkat yogurt (0, 3, 6, dan $9 \mathrm{ml} / \mathrm{kg}) \mathrm{dan}$ lama waktu fermentasi $(24,48$, dan 72 jam) yang diulang sebanyak 5 kali. Bahan yang digunakan adalah kulit nanas, plain yogurt yang mengandung bakteri Lactobacillus delbrueckii subsp. bulgaricus dan Streptococcus salivarius subsp. thermophilus, bahan kimia yang digunakan untuk analisis proksimat protein dan serat kasar kulit nanas fermentasi, larutan saliva buatan McDougall dan cairan rumen. Hasil penelitian menunjukkan perbedaan pengaruh yang nyata $(\mathrm{P}<0,05)$ tingkat yogurt terhadap kecernaan in vitro bahan kering, bahan organik, dan protein kasar tetapi tidak berbeda nyata terhadap kecernaan serat kasar. Waktu fermentasi berpengaruh nyata $(\mathrm{P}<0,05)$ terhadap kecernaan bahan kering, bahan organik, protein kasar, dan serat kasar secara in vitro. Interaksi tingkat yogurt dengan waktu fermentasi memberikan perbedaan pengaruh yang nyata $(\mathrm{P}<0,05)$ terhadap kecernaan bahan kering, bahan organik dan protein kasar tetapi tidak memberikan perbedaan pengaruh nyata terhadap kecernaan serat kasar. Kesimpulan dari penelitian ini bahwa tingkat yogurt $6 \mathrm{ml} / \mathrm{kg}$ dan waktu fermentasi 72 jam dapat meningkatkan kecernaan in vitro bahan kering, bahan organik, dan protein kasar serta menurunkan kecernaan in vitro serat kasar kulit nanas fermentasi.

(Kata kunci: Fermentasi, Kecernaan in vitro, Kulit nanas, Yogurt)

\section{ABSTRACT}

An experiment was conducted to determine the effect of yoghurt level and time of fermentation on in vitro digestibility of dry matter, crude protein and crude fibre of fermented pineapple peel. The experiment was assigned into Completely Randomized Design in factorial with 2 factors that were level of yoghurt $(0,3,6$ and $9 \mathrm{ml} / \mathrm{kg})$ and time of fermentation (24, 48 and 72 hours) and 5 replications each. Materials were pineapple peel, plain yoghurt contained Lactobacillus delbrueckii subsp. bulgaricus dan Streptococcus salivarius subsp. thermophilus, chemicals for proximate analysis of crude protein and crude fibre, artificial saliva or McDougall solution and rumen liquid. Results of this study showed that there was significant effect $(P<0.05)$ of yoghurt level on in vitro digestibility of dry matter, organic matter and crude protein but did not effect significantly on crude fibre in vitro digestibility. Time of fermentation significantly $(P<0.05)$ affect in vitro digestibility of dry matter, organic matter, crude protein and crude fibre. Interaction between yoghurt level and time of fermentation significantly $(P<0.05)$ affected in vitro digestibility of dry matter, organic matter and crude protein but did not affect crude fibre in vitro digestibility. It is concluded that level of yoghurt $6 \mathrm{ml} / \mathrm{kg}$ and time of fermentation 72 hours increase in vitro digestibility of dry matter, organic matter and crude protein and decreased in vitro digestibility of crude fibre of fermented pineapple peels.

(Keywords: Fermentation, In vitro digestibility, Pineapple peel, Yoghurt)

\section{Pendahuluan}

Kulit nanas merupakan limbah pengolahan buah nanas dan belum dimanfaatkan sehingga dapat menjadi sumber pencemaran lingkungan karena mudah berjamur dan menjadi busuk serta asam. Produksi kulit nanas meningkat seiring dengan peningkatan produksi buah nanas dan pengolahan nanas. Hasil pengamatan di lapangan didapatkan bahwa kulit nanas dihasilkan sebanyak 25-35\% dari buah nanas tergantung jenis buah nanas, tingkat kematangan dan tekhnik pengupasan. Badan Pusat Statistik (2014) melaporkan bahwa dalam 17 tahun terakhir (1995-2012), produksi buah nanas di Indonesia meningkat 9,02\% per tahun di mana pada tahun 1995 produksi buah nanas 703.300 ton dan

\footnotetext{
* Korespondensi (corresponding author):

Telp. +62 85378365269

E-mail: nur2612@yahoo.com
} 
pada 2012 mencapai 1.781 .899 ton. Hal ini menunjukkan bahwa pada tahun 2012 produksi kulit nanas mencapai 445-623 ribu ton dan kulit nanas merupakan sumber bahan pakan yang potensial dan ketersediaannya ada sepanjang tahun mengingat buah nanas tumbuh dan berbuah tanpa mengenal musim (Bartholomew et al., 2002). Kulit nanas juga mengandung energi bruto yang cukup tinggi yaitu $4481 \mathrm{kkal} / \mathrm{kg}$ (Wijana et al., 1991) karena kulit nanas mengandung gula reduksi yang mudah terurai. Sruamsiri (2007) melaporkan bahwa kulit nanas mengandung karbohidrat tinggi yang merupakan karbohidrat terlarut dan mudah terdegradasi sebagai sumber energi serta mengandung enzim bromelin yang berguna untuk metabolisme protein. Krueger et al. (1992) menyatakan bahwa kulit nanas mengandung sukrosa, fruktosa, glukosa, dan zat makanan lainnya. Disamping potensinya, penggunaan kulit nanas sebagai bahan pakan ternak terutama untuk ternak unggas terkendala dengan kualitasnya yang rendah dan cepat rusak atau mengalami pembusukan akibat kandungan air yang cukup tinggi. Bardiya et al. (1996) melaporkan bahwa kulit nanas mengandung 19,8\% selulosa dan 11,7\% hemiselulosa. Emaga et al. (2011) melaporkan bahwa 20-30\% serat yang terkandung dalam kulit nanas terukur sebagai neutral detergent fiber (NDF).

Yogurt adalah makanan yang mengandung probiotik hasil fermentasi asam laktat dalam susu oleh Lactobacillus bulgaricus and Streptococcus thermophilus (Bourlioux dan Pochart, 1988) dengan kualitas protein yang terkandung di dalamnya sangat baik dan terjaga selama proses fermentasi (Hewitt dan Bancroft, 1985). El Bashiti (2010) melaporkan bahwa yogurt mengandung bakteri Lactobacillus delbrueckii subsp. bulgaricus dan Streptococcus salivarius subsp. thermophilus. Bakteri Lactobacillus bulgaricus dan Streptococcus thermophilus merupakan bakteri proteolitik dan homofermentatif. Lactobacillus dapat memfermentasi laktosa, fruktosa dan glukosa untuk menghasilkan asam laktat (Limsowtin et al., 2002). Begitu pula dengan Streptococcus thermophilus, mampu memfermentasi laktosa, glukosa, fruktosa, dan sukrosa untuk menghasilkan asam laktat (Pearce dan Flint, 1999). Kombinasi keduanya akan menghasilkan keasaman yang lebih tinggi dibandingkan terpisah (Tamime dan Robinson, 2007). Fermentasi menggunakan bakteri asam laktat (BAL) akan dapat meningkatkan kualitas bahan yang difermentasi karena BAL dapat menghasilkan enzim yang mampu mendegradasi serat (Zubaidah et al., 2010; 2012). Oleh karena itu fermentasi kulit nanas dengan yogurt diharapkan dapat meningkatkan protein dan menurunkan serat kasar kulit nanas yang terkandung sehingga kulit nanas dapat digunakan tidak saja sebagai sumber energi tetapi juga bahan pakan unggas yang mudah dicerna.

Kualitas bahan pakan bukan hanya dapat diukur melalui pengukuran kandungan zat makanannya tetapi juga kecernaan bahan tersebut. Kecernaan bahan dapat diukur secara in vivo dan in vitro. Pengukuran kecernaan secara in vivo membutuhkan waktu lebih lama dan biaya lebih banyak dengan perbedaan hasil yang didapatkan berbeda tidak nyata. Oleh karena itu dilakukan penelitian untuk melihat pengaruh tingkat yogurt dan waktu fermentasi terhadap kecernaan in vitro bahan kering, bahan organik, protein, dan serat kasar kulit nanas fermentasi.

\section{Materi dan Metode}

\section{Materi}

Materi yang digunakan dalam penelitian ini adalah kulit nanas, plain yogurt atau yogurt tanpa rasa yang mengandung bakteri Lactobacillus delbrueckii subsp. bulgaricus dan Streptococcus salivarius subsp. thermophilus, bahan kimia yang digunakan untuk analisis proksimat kandungan protein dan serat kasar kulit nanas fermentasi, larutan saliva buatan atau McDougall dan cairan rumen. Alat yang digunakan terdiri dari timbangan, mesin giling, kukusan, kantong plastik, oven, alat untuk analisis bahan kering, bahan organik, protein dan serat kasar sesuai dengan panduan AOAC (2000), alat untuk mengukur kecernaan in vitro sesuai panduan Tilley dan Terry (1963).

\section{Rancangan percobaan}

Rancangan yang digunakan dalam penelitian ini adalah Rancangan Acak Lengkap pola faktorial $4 \times 3$ dengan 2 faktor yaitu faktor A (tingkat yogurt 0, 3, 6, dan $9 \mathrm{ml} / \mathrm{kg}$ bahan) dan faktor B (waktu fermentasi 24, 48, dan 72 jam). Setiap perlakuan diulang sebanyak 5 kali sehingga didapatkan 60 unit percobaan.

Perlakuan yang diberikan yaitu :

A0 : kulit nanas difermentasi tanpa menggunakan yogurt

A3 : kulit nanas difermentasi menggunakan yogurt $3 \mathrm{ml} / \mathrm{kg} \mathrm{BK}$ kulit nanas

A6 : kulit nanas difermentasi menggunakan yogurt $6 \mathrm{ml} / \mathrm{kg} \mathrm{BK}$ kulit nanas

A9 : kulit nanas difermentasi menggunakan yogurt $9 \mathrm{ml} / \mathrm{kg} \mathrm{BK}$ kulit nanas

B24 : kulit nanas difermentasi selama 24 jam

B48 : kulit nanas difermentasi selama 48 jam

B72 : kulit nanas difermentasi selama 72 jam

Data yang diperoleh dianalisis ragam sesuai rancangan yang digunakan yaitu Rancangan Acak 
Lengkap pola faktorial dengan model matematis sebagai berikut:

$$
\mathrm{Y}_{\mathrm{ij}}=\mu+\alpha_{\mathrm{i}}+\beta_{\mathrm{j}}+(\alpha \beta)_{\mathrm{ij}}+\mathrm{E}_{\mathrm{ijk}}
$$

Keterangan:

$\mathrm{Y}_{\mathrm{ij}} \quad=$ hasil pengamatan untuk faktor A level ke-i,

faktor B level ke-j, pada ulangan ke-k

$\mu \quad=$ rataan umum

$\alpha_{i} \quad=$ pengaruh faktor $A$ pada level ke- $\mathrm{i}$

$\beta_{\mathrm{j}} \quad=$ pengaruh faktor $\mathrm{B}$ pada level ke- $\mathrm{j}$

$(\alpha \beta)_{\mathrm{ij}}=$ interaksi antara A dan B pada faktor A level ke-i, faktor B level ke-j

$\mathrm{E}_{\mathrm{ijk}} \quad=$ galat percobaan untuk faktor A level ke-i, faktor B level ke-j pada ulangan/kelompok ke-k.

Perlakuan yang berbeda nyata terhadap parameter yang diamati diuji dengan Uji Jarak Berganda Duncan (Portable SAS 9.1 for Windows).

Fermentasi kulit nanas. Kulit nanas yang diambil dari desa Tangkit Baru kecamatan Jambi luar kota kabupaten Muaro Jambi dipisahkan dan dibersihkan dari yang rusak dan yang kotor. Kulit nanas yang sudah dibersihkan diukur kadar bahan keringnya. Selanjutnya kulit nanas dicincang, dikeringkan di bawah sinar matahari agar dapat digiling menjadi tepung. Tepung kulit nanas ditambahkan air $(2: 1)$ sehingga kadar air mencapai 60-70\% untuk memenuhi syarat tumbuh bakteri yang akan digunakan dalam proses fermentasi kulit nanas. Selanjutnya dikukus selama 30 menit agar steril dari berbagai macam mikrobia seperti jamur dan bakteri lainnya yang dapat mengganggu proses fermentasi. Setelah itu didinginkan sehingga suhu menjadi $35-40^{\circ} \mathrm{C}$. Selanjutnya kulit nanas dicampur dengan yogurt sesuai perlakuan dan difermentasi secara an aerob (pada kantong plastik tertutup) dengan waktu sesuai perlakuan. Setelah fermentasi selesai dilanjutkan dengan pengukuran kecernaan in vitro bahan kering, protein kasar, dan serat kasar.

Kecernaan in vitro kulit nanas. Pengukuran kecernaan in vitro dilakukan menurut metode Tilley dan Terry (1963) dengan meniru kondisi di dalam tubuh ternak sebenarnya. Satu gram sampel dimasukkan ke dalam botol fermentor dan ditambahkan $80 \mathrm{ml}$ larutan inokulan berupa campuran larutan McDougall yang dibuat sesuai dengan prosedur McDougall (1948) dan cairan rumen. Selanjutnya diinkubasikan secara anaerob selama 48 jam pada suhu $38^{\circ} \mathrm{C}$. Kemudian larutan $\mathrm{HgCl}_{2}$ jenuh diteteskan sebanyak $3 \mathrm{ml}$ untuk mematikan bakteri, ditambahkan pepsin $0,2 \%$ ke dalam tabung dan diinkubasikan kembali dalam shakerbath pada suhu $38^{\circ} \mathrm{C}$ selama 24 jam. Setelah itu residu bahan yang tidak larut disaring dengan kertas Whatman 41 dan dikeringkan. Setiap unit percobaan diulang 5 kali untuk mendapatkan berat sampel yang dibutuhkan dalam analisis bahan kering, bahan organik, protein, dan serat kasar.

\section{Hasil dan Pembahasan}

Kecernaan in vitro bahan kering, bahan organik, protein, dan serat kasar kulit nanas setelah difermentasi dengan tingkat yogurt dan waktu fermentasi yang berbeda dapat dilihat pada Tabel 1 . Hasil analisis ragam memperlihatkan bahwa tingkat yogurt memberikan pengaruh yang nyata $(\mathrm{P}<0,05)$ terhadap kecernaan bahan kering, bahan organik dan protein kasar tetapi tidak nyata mempengaruhi kecernaan serat kasar. Meningkatnya penggunaan yogurt sampai $6 \mathrm{ml} / \mathrm{kg}$ nyata meningkatkan kecernaan bahan kering, bahan organik, protein kasar, dan serat kasar. Pengaruh yang nyata $(\mathrm{P}<0,05)$ juga diperlihatkan oleh faktor waktu fermentasi terhadap kecernaan bahan kering, bahan organik, protein kasar, dan serat kasar secara in vitro. Kecernaan bahan kering, bahan organik, protein kasar meningkat seiring dengan semakin lamanya waktu fermentasi dilakukan tetapi kecernaan serat kasar turun. Interaksi tingkat yogurt dengan waktu fermentasi memberikan pengaruh yang nyata $(\mathrm{P}<0,05)$ terhadap kecernaan bahan kering, bahan organik dan protein kasar tetapi tidak nyata mempengaruhi kecernaan serat kasar.

Terdapatnya pengaruh yang nyata tingkat yogurt terhadap kecernaan bahan kering, bahan organik, dan protein kasar diduga karena kandungan glukosa dalam kulit nanas (Krueger et al., 1992; Raji et al., 2012) yang merupakan non struktural karbohidrat siap dicerna menjadi sumber energi bagi mikrobia rumen (Bailey et al., 2012) sehingga mikrobia rumen meningkat pertumbuhan dan keaktifannya. Mikrobia yang terkandung dalam cairan rumen diantaranya adalah bakteri proteolitik, bakteri yang menghasilkan enzim protease. Peningkatan jumlah bakteri proteolitik akan meningkatkan deaminasi sehingga mengakibatkan peningkatan nilai kecernaan bahan kering, bahan organik dan pada akhirnya dapat meningkatkan kecernaan protein kasar yang merupakan bagian dari bahan organik. Sebagaimana yang dinyatakan oleh Hemalatha dan Anbuselvi (2013), limbah nanas mengandung gula, karbohidrat, dan protein yang digunakan sebagai media zat makanan untuk pertumbuhan mikrobia dan fermentasi menggunakan yeast untuk menghasilkan ethanol dan protein sel tunggal. Jayanegara et al. (2006) menyatakan bahwa peningkatan jumlah bakteri proteolitik akan meningkatkan kecernaan bahan organik yang selanjutnya meningkatkan kecernaan protein. 
Uji Duncan memperlihatkan bahwa peningkatan yogurt nyata $(\mathrm{P}<0,05)$ meningkatkan kecernaan bahan kering, bahan organik, dan protein kasar tetapi tidak nyata meningkatkan kecernaan serat kasar. Kecernaan bahan kering nyata berbeda antara tingkat yogurt 0 dengan 3,6 , dan $9 \mathrm{ml} / \mathrm{kg}$, tingkat yogurt 3 dengan 6 dan $9 \mathrm{ml} / \mathrm{kg}$ tetapi tidak berbeda nyata antara tingkat yogurt 6 dan $9 \mathrm{ml} / \mathrm{kg}$.
Kecernaan bahan organik pada kontrol tidak berbeda dengan perlakuan 3 dan $9 \mathrm{ml} / \mathrm{kg}$ tetapi nyata lebih rendah dibandingkan dengan perlakuan $6 \mathrm{ml} / \mathrm{kg}$. Kecernaan protein kasar perlakuan kontrol relatif sama dengan perlakuan $3 \mathrm{ml} / \mathrm{kg}$ tetapi nyata lebih rendah dibandingkan perlakuan 6 dan $9 \mathrm{ml} / \mathrm{kg}$. Waktu fermentasi selama 24 dan 48 jam memberikan kecernaan bahan kering, bahan organik, dan

Tabel 1. Pengaruh tingkat yogurt, waktu fermentasi, interaksi tingkat yogurt dan waktu fermentasi terhadap kecernaan in vitro bahan kering, bahan organik, protein, dan serat kasar kulit nanas fermentasi (effect of yoghurt level, duration of fermentation, interaction between level of yoghurt and duration of fermentation on in vitro digestibility of dry matter, organic matter, crude protein and fibre of fermented pineapple peel)

\begin{tabular}{|c|c|c|c|c|}
\hline \multirow[b]{2}{*}{ Faktor (factor) } & \multicolumn{4}{|c|}{ Kecernaan (\%) (digestibility (\%)) } \\
\hline & $\begin{array}{l}\text { Bahan kering } \\
(\text { dry matter })\end{array}$ & $\begin{array}{l}\text { Bahan organik } \\
\text { (organic matter) }\end{array}$ & $\begin{array}{l}\text { Protein kasar } \\
\text { (crude protein) }\end{array}$ & $\begin{array}{l}\text { Serat kasar } \\
\text { (crude fibre) }\end{array}$ \\
\hline \multicolumn{5}{|l|}{$\begin{array}{l}\text { Tingkat yogurt }(\mathrm{ml} / \mathrm{kg}) \text { (level of yoghurt } \\
(\mathrm{ml} / \mathrm{kg}) \text { ) }\end{array}$} \\
\hline 0 & $52,17^{\mathrm{c}}$ & $56,95^{\mathrm{b}}$ & $52,68^{\mathrm{c}}$ & $35,43^{\mathrm{a}}$ \\
\hline 3 & $53,29^{\mathrm{b}}$ & $57,68^{\mathrm{b}}$ & $53,62^{\mathrm{bc}}$ & $35,96^{\mathrm{a}}$ \\
\hline 6 & $54,32^{\mathrm{a}}$ & $59,30^{\mathrm{a}}$ & $54,78^{\mathrm{b}}$ & $37,23^{\mathrm{a}}$ \\
\hline 9 & $54,54^{\mathrm{a}}$ & $57,93^{\mathrm{b}}$ & $57,47^{\mathrm{a}}$ & $36,60^{\mathrm{a}}$ \\
\hline \multicolumn{5}{|l|}{$\begin{array}{l}\text { Waktu fermentasi (jam) (duration of } \\
\text { fermentation (hours)) }\end{array}$} \\
\hline 24 & $53,12^{\mathrm{b}}$ & $56,47^{\mathrm{c}}$ & $54,29^{\mathrm{b}}$ & $37,05^{\mathrm{a}}$ \\
\hline 48 & $53,48^{\mathrm{b}}$ & $57,59^{\mathrm{b}}$ & $53,57^{\mathrm{b}}$ & $36,82^{\mathrm{a}}$ \\
\hline 72 & $54,15^{\mathrm{a}}$ & $59,84^{\mathrm{a}}$ & $56,06^{\mathrm{a}}$ & $35,05^{\mathrm{b}}$ \\
\hline \multicolumn{5}{|l|}{$\begin{array}{l}\text { Tingkat yogurt } \mathrm{x} \text { waktu fermentasi (level } \\
\text { of yoghurt } x \text { duration of fermentation) }\end{array}$} \\
\hline $0 \times 24$ & $52,23^{\mathrm{a}}$ & $55,60^{\mathrm{b}}$ & $52,96^{\mathrm{a}}$ & $35,54^{\mathrm{a}}$ \\
\hline $0 \times 48$ & $52,07^{\mathrm{a}}$ & $57,21^{\mathrm{ab}}$ & $53,28^{\mathrm{a}}$ & $35,77^{\mathrm{a}}$ \\
\hline $0 \times 72$ & $52,23^{\mathrm{a}}$ & $58,04^{\mathrm{a}}$ & $51,81^{\mathrm{b}}$ & $34,97^{\mathrm{a}}$ \\
\hline $3 \times 24$ & $52,49^{\mathrm{a}}$ & $54,35^{\mathrm{b}}$ & $52,39^{\mathrm{b}}$ & $37,17^{\mathrm{a}}$ \\
\hline $3 \times 48$ & $53,53^{\mathrm{a}}$ & $58,31^{\mathrm{a}}$ & $51,90^{\mathrm{b}}$ & $35,32^{\mathrm{a}}$ \\
\hline $3 \times 72$ & $53,85^{\mathrm{a}}$ & $60,40^{\mathrm{a}}$ & $56,57^{\mathrm{a}}$ & $35,40^{\mathrm{a}}$ \\
\hline $6 \times 24$ & $53,80^{\mathrm{a}}$ & $58,19^{\mathrm{b}}$ & $54,80^{\mathrm{a}}$ & $38,85^{\mathrm{a}}$ \\
\hline $6 \times 48$ & $54,53^{\mathrm{a}}$ & $59,04^{\mathrm{ab}}$ & $53,39^{\mathrm{a}}$ & $38,90^{\mathrm{a}}$ \\
\hline $6 \times 72$ & $54,62^{\mathrm{a}}$ & $60,66^{\mathrm{a}}$ & $56,16^{\mathrm{a}}$ & $33,93^{\mathrm{a}}$ \\
\hline $9 \times 24$ & $53,97^{\mathrm{b}}$ & $57,73^{\mathrm{ab}}$ & $57,01^{\mathrm{ab}}$ & $36,64^{\mathrm{a}}$ \\
\hline $9 \times 48$ & $53,77^{\mathrm{b}}$ & $55,82^{\mathrm{b}}$ & $55,69^{\mathrm{b}}$ & $37,27^{\mathrm{a}}$ \\
\hline $9 \times 72$ & $55,90^{\mathrm{a}}$ & $60,25^{\mathrm{a}}$ & $59,72^{\mathrm{a}}$ & $35,88^{\mathrm{a}}$ \\
\hline \multicolumn{5}{|l|}{ Sumber keragaman (source of variance) } \\
\hline Tingkat yogurt (level of yoghurt) & * & * & * & ns \\
\hline $\begin{array}{l}\text { Waktu fermentasi (duration of } \\
\text { fermentation) }\end{array}$ & $*$ & $*$ & $*$ & * \\
\hline $\begin{array}{l}\text { Tingkat yogurt } \mathrm{x} \text { waktu fermentasi } \\
\text { (level of yoghurt } x \text { duration of } \\
\text { fermentation) }\end{array}$ & $*$ & $*$ & $*$ & ns \\
\hline
\end{tabular}


protein kasar yang sama dan nyata lebih rendah dibandingkan yang difermentasi dalam waktu 72 jam. Kecernaan bahan organik kulit nanas yang difermentasi dalam waktu 24 jam nyata lebih rendah dibandingkan yang difermentasi dalam waktu 48 dan 72 jam, sedangkan kecernaan serat kasar nyata lebih rendah pada kulit nanas yang difermentasi dalam waktu 72 jam dibandingkan dengan 24 dan 48 jam. Terlihat penurunan yang nyata kecernaan serat kasar dengan semakin meningkatnya waktu fermentasi yang dilakukan. Hal ini menunjukkan bahwa bakteri yang terkandung di dalam yogurt yaitu Lactobacillus delbrueckii subsp. bulgaricus dan Streptococcus thermophilus menghasilkan kecernaan bahan kering lebih tinggi ketika difermentasi lebih dari dua hari. Bakteri Lactobacillus dan Streptococcus terus tumbuh sampai fermentasi berjalan selama 72 jam sehingga terjadi peningkatan biomasa. Hal ini terlihat dari perubahan warna permukaan media tumbuh dari abu-abu kecoklatan menjadi putih merata di semua permukaan setelah 72 jam. Kondisi ini mengakibatkan semakin banyak bahan kering yang dapat didegradasi dan pada akhirnya kecernaan bahan kering akan meningkat. Jude-Ojei (2010) menyatakan bahwa selama proses fermentasi akan terjadi pertumbuhan mikrobia yang digunakan dalam fermentasi sehingga dapat meningkatkan biomasa pada produk fermentasi. Itelima et al. (2013) melaporkan bahwa kulit nanas yang difermentasi dengan A. niger and $S$. cerevisiae selama 7 hari menghasilkan biomasa lebih banyak dibandingkan kontrol dan waktu yang lebih pendek. Semakin meningkat waktu fermentasi dilakukan maka akan terjadi peningkatan produksi air sehingga kandungan bahan kering turun (Hajar et al., 2012).

Peningkatan kecernaan protein kasar pada kulit nanas yang difermentasi dengan bakteri Lactobacillus delbrueckii subsp. bulgaricus dan Streptococcus thermophilus sejalan dengan peningkatan kecernaan bahan kering dan bahan organik yang diduga karena meningkatnya jumlah mikrobia yang tumbuh selama proses fermentasi. Mikrobia tersebut dapat mensintesis protein selama masa fermentasi karena merupakan bakteri proteolitik. Sebagaimana yang dinyatakan Jamila et al. (2009) bahwa selama proses fermentasi menggunakan Lactobacillus sp akan terjadi peningkatan jumlah mikrobia yang dapat meningkatkan sintesa protein dan menghasilkan asam amino. Hewitt dan Bancroft (1985) menyatakan bahwa selama proses fermentasi susu, perlakuan panas dan produksi asam yang dihasilkan turut berperan dalam meningkatkan kecernaan protein yogurt. Kualitas protein pada yogurt tetap terjaga dengan baik selama proses fermentasi.
Penelitian terakhir menunjukkan peningkatan kecernaan serat kasar belum nyata terjadi dengan meningkatnya tingkat yogurt yang digunakan, akan tetapi semakin lama waktu fermentasi dilakukan, kecernaan serat kasar semakin menurun. Hal ini berbeda dengan yang dilaporkan peneliti sebelumnya bahwa bakteri Lactobacillus bulgaricus (Jin et al., 1997) dan Streptococcus thermophilus (Sneath et al., 1994) memiliki kemampuan mendegradasi serat kasar. Zubaidah et al. (2010; 2012) melaporkan bahwa selama fermentasi bakteri asam laktat akan memanfaatkan nutrisi seperti karbohidrat, protein, dan serat pangan sebagai sumber energi untuk pertumbuhan, pembentukan sel, dan biosintesa produk-produk metabolit. selanjutnya dinyatakan pada media fermentasi bekatul kadar serat kasar pada jam ke-0 hingga jam ke-12 mengalami penurunan dan semakin tinggi total BAL semakin banyak BAL yang memanfaatkan serat untuk metabolisme sel dan menghidrolisisnya menjadi senyawa sederhana untuk difermentasi oleh BAL melalui glikolisis menjadi asam. El Bashiti et al. (2010) merekomendasikan untuk mempersingkat waktu inkubasi dalam proses fermentasi susu guna menghasilkan yogurt yang berkualitas dan waktu inkubasi yang baik terjadi kurang dari 8 jam.

\section{Kesimpulan}

Disimpulkan bahwa penambahan yogurt dan waktu fermentasi dapat meningkatkan kecernaan bahan kering, bahan organik, dan protein kasar serta menurunkan kecernaan serat kasar kulit nanas fermentasi pada tingkat penggunaan yogurt $6 \mathrm{ml} / \mathrm{kg}$ yang difermentasi dalam waktu 72 jam.

\section{Ucapan Terima Kasih}

Ucapan terima kasih disampaikan kepada DP2M atas bantuan dana penelitian hibah bersaing tahap pertama tahun 2013, Rektor Universitas Jambi, Dekan Fakultas Peternakan Universitas Jambi, Ketua Lembaga Penelitian Universitas Jambi beserta jajarannya atas izin dan dukungan sarana prasarana, laboran dan mahasiswa program sarjana yang terlibat dalam penelitian ini sehingga penelitian dapat berjalan dengan baik.

\section{Daftar Pustaka}

AOAC. 2000. Official Methods of Analysis of AOAC International. $17^{\text {th }}$ ed. Horwitz, W. (ed). Gaithersburg, MD. 
Badan Pusat Statistik. 2014. Produksi Buah-buahan dan Sayuran Tahunan di Indonesia, 19952013. Available at http://www.bps.go.id/ tab_sub/view.php?kat=3\&tabel=1\&daftar $=1$ \&id_subyek $=55 \&$ notab $=15$. Accession date: 20 Januari, 2014.

Bailey, E. A., E. C. Titgemeyer, K. C. Olson, D. W. Brake, M. L. Jones and D. E. Anderson. 2012. Effects of ruminal casein and glucose on forage digestion and urea kinetics in beef cattle. J. Anim. Sci. 90: 3505-3514.

Bardiya, N., D. Somayaji and S. Khanna. 1996. Biomethanation of banana peel and pineapple waste. Bioresource Technol. 58: 73-76.

Bartholomew, D. P., R. E. Paull and K. G. Rohrbach. 2002. The Pineapple: Botany, Production and Uses. CABI Publishing, Wallingford.

Bourlioux, P. and P. Pochart. 1988. Nutritional and health properties of yogurt. World Rev. Nutr. Diet. 56: 217-258.

El Bashiti, T. A. I. 2010. Production of yoghurt by locally isolated starters : Streptococcus thermophilus and Lactobacillus bulgaricus. Short Research Communication. Nat. Sci. (ICBAS Special Issue) 12: 56-58.

Emaga, H. T., J. Bindelle, R. Agneesens, A. Buldgen, B. Wathelet and M. Paquot. 2011. Ripening influences banana and plantain peels composition and energy content. Trop. Anim. Health Prod. 43: 171-177.

Hajar, N., S. Zainal, O. Atikah and T. Z. M. Tengku Elida. 2012. Optimization of ethanol fermentation from pineapple peel extract using response surface methodology (RSM). World Acad. Sci. Eng. Technol. 72: 641-647.

Hemalatha, R. and S. Anbuselvi. 2013. Physicohemical constituents of pineapple pulp and waste. J. Chem. Pharm. Res. 5: 240-242.

Hewitt, D. and H. J. Bancroft. 1985. Nutritional value of yoghurt. J. Dairy Res. 52: 197-207.

Itelima, J., F. Onwuliri, E. Onwuliri, I. Onyimba and S. Oforji. 2013. Bio-ethanol production from banana, plantain and pineapple peels by simultaneous saccharification and fermentation process. Int. J. Environ. Sci. Dev. 4: 213-216.

Jamila, F. K. Tangdilintin, dan R. Astuti. 2009. Kandungan protein kasar dan serat kasar pada feses ayam yang difermentasi dengan Lactobacillus Sp. Seminar Nasional Teknologi Peternakan dan Veteriner, Pusat Penelitian dan Pengembangan Peternakan. Bogor.
Jayanegara, A., A. S. Tjakradidjaja, dan T. Sutardi. 2006. Fermentabilitas dan kecernaan in vitro ransum limbah agroindustri yang disuplementasi kromium organik dan anorganik. Media Peternakan 29: 54-62.

Jin, L. Z., Y. W. Ho, N. Abdullah and S. Jalaldin. 1997. Probiotic in poultry: Models of action. J. Worlds Poult. Sci. 53: 351-368.

Jude-Ojei, B. S. 2010. Effect of fermentation on the proximate composition of ripe pineapple (Ananas comosus). Thesis. Department of Microbiology, Federal University of Technology. Akure.

Krueger D. A., R. G. Krueger and J. Maciel. 1992. Composition of pineapple juice. J. AOAC Int. 75: 280-282.

Limsowtin, G. K. Y., M. C. Broome and I. B. Powell. 2002. Lactic acid bacteria, taxonomy. In: Encyclopedia of Dairy Science. $\mathrm{H}$. Roginski, J. Fuquay, P. Fox. (eds). Academic Press. London.

McDougall, E. I. 1948. Studies on ruminant saliva. 1. Composition and output of sheep's saliva. Biochem. J. 43: 99-109.

Pearce, L. and S. Flint. 1999. Streptococcus thermophilus. In: Encyclopedia of Dairy Science. H. Roginski, J. Fuquay, P. Fox (eds). Academic Press. London.

Raji, Y. O., M. Jibril, I. M. Misau and B. Y. Danjuma. 2012. Production of vinegar from pineapple peel. Int. J. Adv. Sci. Res. Technol. 3: 656-666.

Sneath, P. H. A., N. S. Mair, M. E. Sharpe and J. G. Holt. 1994. Bergey's Manual of Determinative Bacteriology, $9^{\text {th }}$ ed. William and Wilkins. Baltimore.

Sruamsiri, S. 2007. Agricultural wastes as dairy feed in Chiang Mai. Anim. Sci. J. 78: 335341.

Tamime, A. Y. and R. K. Robinson. 2007. Yoghurt Science and Technology. $3^{\text {rd }}$ ed. Woodhead Publishing in Food Science, Technology and Nutrition. Cambridge.

Tilley, J. M. A. and R. A. Terry. 1963. A two-stage technique for the in vitro digestion of forage crops. J. Br. Grassland Soc. 18: 104-111.

Wijana, S., S. Kumalaningsih, A. Setyowati, U. Efendi, dan N. Hidayat. 1991. Optimalisasi penambahan tepung kulit nanas dan proses fermentasi pada pakan ternak terhadap peningkatan kualitas nutrisi. Laporan Penelitian. Hibah Agricultural Research Management Project (ARMP) Departemen Pertanian Republik Indonesia. Universitas Brawijaya. Malang. 
Zubaidah, E., E. Saparianti, dan J. Hindrawan. 2012. Studi aktivitas antioksidan pada bekatul dan susu skim terfermentasi probiotik (Lactobacillus plantarum B2 dan Lactobacillus acidophillus). Jurnal Teknologi Pertanian 13: 111-118.
Zubaidah, E., N. Aldina, dan F. C. Nisa. 2010. Studi aktivitas antioksidan bekatul dan susu skim terfermentasi bakteri asam laktat probiotik (Lactobacillus plantarum J2 dan Lactobacillus casei). Jurnal Teknologi Pertanian 11: 11-17. 